Österreichische Akademie der Wissenschaften / Austrian Academy of Sciences AAS WORKING PAPERS IN SOCIAL ANTHROPOLOGY

Volume 14

Thomas Fillitz

\title{
CHALLENGING
}

\section{THE GLOBAL ART WORLD}

Anthropological Perspectives on Global Art

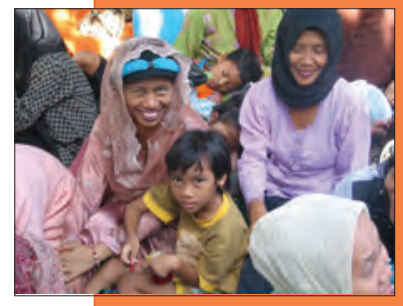

Itring in

Band 14

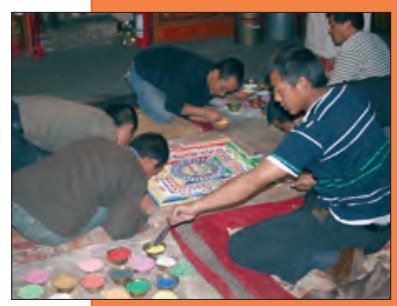




\section{AAS Working Papers in Social Anthropology / \\ ÖAW Arbeitspapiere zur Sozialanthropologie}

ISSN: $1998-507 \mathrm{X}$

doi: $10.1553 /$ wpsa14

ISBN: 978-3-7001-6856-0

Wien 2010

\section{Editors / Herausgeber:}

Andre Gingrich \& Guntram Hazod

(C) Institut für Sozialanthropologie

Zentrum Asienwissenschaften und Sozialanthropologie

Österreichische Akademie der Wissenschaften

Prinz-Eugen-Straße 8-10

A-1040 Wien

Fax: 01/ 51581-6450

E-Mail: sozialanthropologie@oeaw.ac.at 


\title{
CHALLENGING THE GLOBAL ART WORLD
}

\author{
Anthropological Perspectives on Global Art*
}

\author{
Thomas FiLLITZ
}

\section{Introduction}

On the occasion of the exhibition "An/Sichten. Malerei aus dem Kongo 1990-2000" (Jewsiewicki and Plankensteiner 2001) at the Museum für Völkerkunde in Vienna, a strong critique was raised: why was contemporary art from the Congo exhibited in (appropriated by) a museum of ethnography, and not where these artists should be exhibited, namely in the museum of modern art. In a telephone interview the artist and art critique Olu Oguibe replied to the question, why contemporary art of African artists should not be exhibited in a museum of ethnography: "because they are primitivising us!"' I am mentioning this brief example to show a problematic of the work of representation. Actually, Oguibe's harsh statement should be considered in two ways: firstly in relationship to practices of exhibiting of artworks of artists from outside the European-North American art world, and second, in relationship to the representation of African, Asian, etc. societies and cultures in museums of ethnography.

The former aspect relates to a hegemonic power practice in the European-North American art world which consisted in displacing artists from African countries out of the institutions of modern art in Europe and North America. It is, furthermore, the debate whether artworks need sociocultural contextualisation or not. The latter argument forces us to rethink whether museums of ethnography do represent societies or cultures - what kind of societies may we actually experience with a visit to such an institution. Do we really get some knowledge of what is daily life, or ritual life in societies all around the globe? Don't we rather get some constructed knowledge of other societies, in which the old and foreign prevail?

These brief introductory remarks conduct me to the two topics, I intend to discuss in this paper:

(1) In the first part, I want to scrutinize about the work of the Anthropology of Art - should it consider more in-depth dialogues with art history, or how may it be consistently placed as a sub-discipline of Social and Cultural Anthropology? Marcus Banks and Howard Morphy have suggested in 1997 to consider the Anthropology of Art as part of a larger sub-discipline, Visual Anthropology. Besides the study of art in societies around the globe, that later discipline would include the study of pictures (photography and film) as documents of ethnographic enquiry, either by making them, or by analysing those in archives ... Visual Anthropology further would focus on pictures used by various professional groups, like the use and deciphering of images in medicine, or those used in forensic methods by police, and nowadays those we encounter at security checks in airports or official buildings, or video surveillance (CCTV!).

\footnotetext{
* I would like to thank Andre Gingrich for giving me the opportunity to present these ideas at the Institute for Social Anthropology of the Austrian Academy of Sciences, and to Gebhard Fatacek for his kind organisation of the meeting.

${ }^{1}$ Personal communication by journalist Matthias Dusini of the Viennese journal Falter in spring 2001.
} 
(2) This leads me to the second corpus of reflection, about the research programme of Anthropology within Modernity. For twenty years, we have been well acquainted with the study of processes of globalisation, and have aimed at adapting the method of field research to new needs, such as multisited field research (Marcus 1995).

Following Anthropology's reflexive tradition, we may nevertheless wonder about our research practices, whether ethnographic field research remains in whichever form particularistic, bounded to specific experiences of social agents, and confined to more local narratives. Englund and Leach for instance challenge the ethnography of meta-narratives, and position Anthropology's relevance well embedded within the framework of ethnography as a practice of reflexive knowledge production (Englund and Leach 2000). They place their argument in line with Dell Hymes's reflexivity (Hymes 1972), which has nothing to do with the "Writing Culture" (Clifford and Marcus 1986) quest of representation in Anthropology, but with the relevance of anthropological knowledge production. They remind us the tradition of "realist ethnography," i.e. "fieldwork as lived experience indispensable for anthropological knowledge" (Englund and Leach 2000: 229). Theirs is the claim for a new reflexive anthropology which would renew the "discipline's old concern" (Englund and Leach 2000: 239). Of course, this ethnographic reflexive knowledge production may rely on different forms of reflexivity, being e.g. the Cartesian introspection of the "cogito ergo sum," Bourdieu's participant objectivation (2003) - making objective the social possibilities of knowledge production, or Hervik's consideration of fieldwork as shared reasoning in the field - an intersubjective, dialogical reflexivity (Hervik 1994).

Of course I contend in line with many esteemed colleagues that Anthropology has to engage with Modernity, in the sense of unveiling various, possibly conflicting cultural processes and narratives of modernisation (cf. Kahn 2001). But in doing so, I also suggest to look very closely how Anthropology is engaging in such researches. This is more and more important given the blurring of disciplinary boundaries, as articulated in the politics of academia with buzzwords like interdisciplinarity or transdisciplinarity. I too would include in this process the very free use of theories and concepts of outstanding scholars. I wonder, however, why researches on governance, identity, and postcolonialism enhance, nearly without reflexive moment, references to Michel Foucault or Stuart Hall, or that any anthropological work on visual culture is too often well placed within the semiotic methods of either Roland Barthes or Charles Peirce.

As stated earlier, while the fist part of this paper is related to programmes of the Anthropology of Art since the 1990s, the second part of this paper draws on my ongoing research interest in the global art world and art biennales, and in particular on Dak'Art, the art biennale of Dakar. Both parts of this paper however are fed by the concern, I just have expressed, namely how to be anthropological while relying and interconnecting with powerful concepts and theories of other disciplines.

\section{Anthropology of Art}

There was, in the 1990s, a search for repositioning the Anthropology of art within the overall discipline. Two of these endeavours were most prominent in the UK, on the one hand the programme of an Anthropology of Aesthetics advocated by Jeremy Coote and Anthony Shelton (1992). The other one is Alfred Gell's “Art and Agency” (1998). ${ }^{2}$

\footnotetext{
${ }^{2}$ Posthumous edited by Nicholas Thomas.
} 
Research in aesthetics was well established in Anthropology since the 1960s, mainly as the study of standards of beauty and respective indigenous evaluative criteria. Coote and Shelton, however, present an Anthropology of Aesthetics as sub-discipline to mainstream Anthropology, which is not the study of criteria of beauty. They instead focus on notions of aesthetics as ways how people of different cultures see the world. The study of these visual worlds then would include the ways, how people talk about this world, how they describe it, how they intervene via art objects and material culture, basically including all areas of their cultural life (Coote and Shelton 1992: 9f.). For both these authors then, the material art works "offer a prime medium for beginning the intellectual exploration of other societies" (ibd., p. 3). This however needs the recognition that artworks play not only a secondary role as compared to political or symbolic practices within which they are used.

I would like to stress here that Coote's and Shelton's ideas are not so new: actually German anthropologists Brigitta Benzing (1978) and Sylvia Schomburg-Scherf (1986) have advanced the research in aesthetics not as the study of systems of judgement of beauty, but of a concept of aesthetics by which people are structuring the world they are living in. The Anthropology of Aesthetics, according to them, should be conceived as expression of such ordering of practices in everyday life in relation to art.

Alfred Gell intends to embed the Anthropology of Art well within the overall Social Anthropology. Gell is against an aesthetic Anthropology, as he considers this to be the study of evaluative systems. But the artistic quality of, say, an Asmat shield (South-West New Guinea), is no matter of beauty appreciation during a battle. He too is against semiotic or symbolic approaches, as these belong to considerations of art as meaning and communication. Gell radically advocates that art is about doing, an Anthropology of art therefore must be connected to theories of agency.

He seeks to produce his anthropological theory of art "which has affinities towards other anthropological theories" (Gell 1998: 9). Understanding Anthropology as a social discipline, social relations are the subject matter, and the anthropological theory of art has to account "for the production and circulation of art objects as a function of this relational context" (Gell 1998: 11).

Art is to change the world, Alfred Gell thereafter formulates two major concepts: efficacious agency and distributed mind. (1) Art objects may take a mediating role in the social process - drawing on Marcel Mauss' concept of the gift (Mauss 1950). Seeing the splendour of an artwork instigates the beholder to agency. The warrior for instance, who is confronted with the artistic beauty of the Asmat shield, rather may see in these carvings the product of non-human forces (spirits), which are allies of his enemy.

(2) Relying on fractal concepts developed by Roy Wagner and Marilyn Strathern in Melanesian social contexts, Gell transforms Strathern's concept of the distributed person (Strathern 1988) into the one of the distributed mind: a person and person's mind correspond to the spread and dispersal of material objects (Gell 1998: 222f.). This concept helps Gell to analyse the ouvre of an artist, and/ or connecting a singular work or an œuvre to the artworks produced in the history of art. ${ }^{3}$

A different approach, and which is much more embedded within processes of globalisation, is the concept of a "critical Anthropology of art" of Marcus and Myers (1995). Instead of "translating"

${ }^{3}$ This corresponds to Arthur Danto's notion of art world, an ideal community of all artworks created in history (Danto 1965). 
artworks to audiences in Europe and North America, they propose to analyse the flow of art objects into the European-North American art world, which ones this art world is appropriating, which ones are rejected, and the possible ways of circulation in particular institutions. Marcus and Myers suggest that the critical anthropological approach would consist in unravelling the broader contexts of those practices, i.e. the production of images of other cultures, or, what Olu Oguibe has called the "primitivising" of contemporary artists from other regional art worlds. Art, according to them, is a central field where difference, identity, and cultural values are produced and negotiated, where discourse becomes possible.

The consequences of this approach are: (1) there is not one and only (essential) meaning of artworks we anthropologists have to grasp. Rather, we should strive to explain how, during such cultural flows, meanings are transformed, and how hegemonic power strategies are enacted, for the European-North American art world to keep control of these flows. (2) This further allows for changes of perspective. Against the evaluation of artworks from where ever according to unitary standards, anthropologists are well suited to consider the complexity of artworks from regional art worlds, with either no connection to Occidental art history, or with multiple connections to artistic expressions from different local, regional, global cultural contexts. Anthropological research may then relate the change of meaning production during the traffic of pictures to changes and shifts within these cultural connections.

\section{The Global Culture of Art Biennales, and Dak'Art}

Besides the focus on cultural flows in the context of processes of globalisation, there emerged another notion, the one of global culture (Featherstone 1991). Unfortunately, debates on this topic directly lead into debates of cosmopolitans, or cosmopolitanism. We may understand global culture as "an organisation of diversity" (Hannerz 1991: 237), "a region of persistent cultural interaction and exchange" (Featherstone 1991: 6), and it is created either through "the interconnectedness of varied local cultures, as well as through the development of cultures without a clear anchorage in any one territory" (Hannerz 1991: 237).

I would like to apply this notion of global culture to a specific development within the global art world. I am interested here in the question where do we find contemporary or global art. ${ }^{4}$ There are two major systems of institutions in this context, museums of modern art, and art biennales. Although museums of modern art now claim to be museums of contemporary art, partly by simply changing their name, these institutions have, as Stuart Hall emphasises, a tradition, a history, a specific gaze (Hall 2001: 22). These museums are locally oriented, with historically grown collections, and largely local sponsors, and local audiences. Furthermore, their practices of collecting and of exhibiting are strongly determined by the structures of the local or regional art world. With the exception of a few exhibitions, these museums are not the places for displaying and collecting global art, at least not at the moment. ${ }^{5}$

\footnotetext{
${ }^{4}$ I consider global art as the production of contemporary art where ever in the world; global art refers to diversity in art production at a global scale, enhanced interconnections with many centres, although hegemonic standards (e.g. what is contemporary?) of the European-North American art world, and power relations within the global art world persist. For a differentiation between "world art" and "global art" see Belting 2007.

${ }^{5}$ I would place in the same format of world art the art market's fairs, like Art Basel, Art Basel Miami, Frieze Art (London), or Art Cologne, etc.
} 
The first art biennales were the one of Venice (1895), which was and still largely is built on a competition among national pavilions, ${ }^{6}$ around the same concept the one of São Paolo (1951), then documenta (1955) in Kassel, nowadays worldwide the most influential of such a global exhibition type, and Sidney (1973). The latter two were no more conceived as spaces of national competition, and introduced the principle of a main curatorial theme.

The creation of art biennales between the 1980s and today represents a new institutional format, as many of these institutions were created outside the European-North American art world: 1984 Cairo, La Havana, and Istanbul, 1990 (1992) Dak’Art, 1995 Johannesburg, and Gwangju, 2003 DarEs-Salam, etc. Today, there are at least eighty art biennales around the world, about half of them outside the European-North American art world, and thirty of them being organised each year. This dimension also may turn our attention to the global and local economic impact of such venues.

As main features of these biennales I would like to mention: (1) travelling curators (e.g. René Block, Okwui Enwezor, Catherine David, Hou Hanoun, Gerardo Mosquera, etc.), artists, and elite audiences; (2) intercultural curatorial boards, 7 in order to cope with the multiple global art practices - one could also speak of a "global division of labour" (Bydler 2004: 14ff.). On the one hand biennales represent a principle, which is interconnecting art creations of the world that earlier seemed totally unconnected (Enwezor 2003). On the other one, according to René Block, the most important ones are influencing the global art production - and these are positioned within the European-North American art world. Although we may consider the system of art biennales as a global culture, organising the diversity of art creations and of their display, those in places in Europe and North America are events shaping contemporary art production, whereas those in Third World countries rather are sites to build-up intercultural connections, thus slightly changing the hegemonic relationships within the global art world (McEvilley 1993: 8).

Besides these common features, one needs to mention as well the differences between these art biennales. Firstly, not all of them have the same global impact. Venice and documenta in Kassel are for sure globally most important, São Paolo was intended to induce the discourse between European avant-garde and the one in Latin America. La Havana has positioned itself as "the" biennale of Third World art production with its second edition in 1986. Gwangju has by now a tremendous impact in South-East Asia, and slightly less on a global scale. Cairo is connected mostly to the Arabian Peninsula, whereas Istanbul is expanding between Western Europe and Asia, while Dak'art - as we shall see - is conceived as the institution par excellence for visualising contemporary art of Africa.

There are other differentiating features, which have more to do with local political situations. As mentioned earlier, Venice was founded in the aftermath of the former World Fairs as a new platform for the competition between nation-states in the domain of cultural affairs. Documenta in Kassel should bring Germany back into contemporary art world discourses after the devastating impact of the Nazi Regime. Gwangju goes back to the upheaval of students in 1980 against the dictatorship of Chyu Doo-Hwan, and the brutal oppression by the South-Korean army; it therefore became a symbol of Korean democracy. Johannesburg's creation goes back to the first free elections in South Africa in 1994, and was intended to reintegrate the city after the times of boycott against Apartheid back into the cultural arena, and to position it on the political and economic map of world cities.

\footnotetext{
${ }^{6}$ This was a continuation of the concept of World Fairs, but focussing only on visual arts.

${ }^{7}$ A notion created by the Cuban curator Gerardo Mosquera.
} 
In the remaining part of this section, I shall develop some dimensions of the biennale of Dakar, which make it particular within the global culture of art biennales. I am basing my analysis on Turner's concept of the arena "a framework - .. - which manifestly functions as a setting for antagonistic interaction ..." (Turner 1974: 133). I view the arena as a more immediate, dynamic context for social interactions, whereas Bourdieu's concept of the field (champ) is more related to the analysis of different institutions within a common art space (Bourdieu 1992: 254). In my particular analysis, I shall draw on State narratives, comments by Senegalese artists I spoke with, and comments of critiques.

The Biennale of Dakar, Dak'Art, was founded in 1992 as international art biennale under President Abdou Diouf. ${ }^{8}$ It is stated officially that it was an initiative of the Ministry of Culture, which still nowadays acts as central organiser. There was no venue in 1994, and with its second edition in 1996, it was transformed into the Biennale of Contemporary African Art. According to the official vision, and with the support of France and the European Union, Dak'Art was to become the showcase par excellence of art of Africa to the global art world. ${ }^{9}$ Later, with its sixth venue in 2004, the organisers started focusing on its resolutely "pan-African exhibition" (Diamond 2004: 15).

The claim of the Senegalese government over Dak'art was expressed as soon as with the venue of 1992, when artists were pushed to the backstage of the event (personal interviews 2008). Governmental rhetoric further highlighted that Dak'Art is a representation of Dakar as burgeoning crossroad of cultures, much in the sense of Senghor's old universalist claim for a new civilisation de l'universel. From that viewpoint Dak'Art could be positioned in the tradition of the "Premier Festival des Arts Nègres" in Dakar (1966), which was created by President Senghor.

Senegalese artists however insist that they envisioned in the 1980s the institutionalisation of an art biennale as a means for entering an intense dialogue with artists from the global art world, a forum, which they felt was totally missing, and heavily needed. Since the mid-1980s, they had been organising yearly national salons of art in Dakar, one-week events, for producing a public platform of visibility of their cultural contribution. According to artists I interviewed, the idea of Dak'Art was a consequence of these small, local salons. El Haji Sy, then President of the "Association Nationale des Artistes Plasticiens du Sénégal," confronted the President of the State Abdou Diouf in his opening address to the exhibition "Art Against Apartheid" (Dakar 1986), claiming the need for a wider arena of art discourses (El Haji Sy 1995: 234f.). Against the State's claims for the impulse and initiative of the biennale, two interlocutors expressed to me: "They have stolen our biennale!" (personal interviews 2008). Also, as a revolt against the State's appropriation of the biennale, two prominent local artists refused any participation in the first event.

The first biennale in 1992 actually was an attempt of internationalism - although few artists from a few non-African countries did participate at this venue: one artist per country, from eight European countries, three Latin American, five Caribbean ones, two North American, and four Asian ones. At the venue of 1996, the gaze on contemporary African art practices was strongly dominated

\footnotetext{
${ }^{8}$ There was a first art biennale in 1990 combining literature and visual arts.

${ }^{9}$ At sub-Saharan West African scale, and under the constraints of French cultural and economic politics, contemporary art forms are distributed among Francophone countries: Dak'Art is in so far differentiated from the biennale of photography in Bamako, the festival of film in Ouagadougou, and the festival of dance in Abidjan.
} 
by artists from Francophone countries: the vast majority of selected artists came from Senegal, further from other nine Francophone countries, five Anglophone, and two Lysophone ones.

Finally, the insistence of the Senegalese State and its European partners on the categorical African dimension of Dak'Art in respect to the artists, and the rigorous selection criterion - artists had to be citizens of an African state in order to be considered for the official venue - lead to another development in 2000. All artistic activities in Dakar, which so far were placed outside the official global event, were then loosely united under the label of "Dak'Art Off." This latter became a major institution of artistic dynamics in Dakar's public spaces, and allowed interventions of artists from outside Africa. In 2006 for instance, there were 84 artists selected for the official exhibition, while there were 114 artistic interventions (of varying quality) all around the city under the auspices of Dak'Art Off. Actually, any artist could participate in this space, as it operates without any qualitative selection criterion.

The need for change of the concept of the biennale was actually claimed as well by critiques, and artists from the diaspora in Europe and North America. Major topics were: regarding the 1992 venue that it was a misguided faith in the global art circuit (Deliss 1993); regarding the venue of 1996 (1) that the intention to global interaction had nothing to do with a Pan-African dimension which the biennale should become (Biggs 1996), and (2) that the African regionalism was not representing the contemporary art production of the continent; until the venue of 2004, (3) that Dak'art should as well include artists from the African diaspora. Critiques further denounced (4) that it is not enough embedded within the local population (not taking into account Dak'Art Off) - but mostly oriented towards the international elite specialists, and audience, and (5) that it should try to be more than a culture of spectacle as many other biennales (Araeen 2003), etc. These arguments from international critique, and from artists living in the diaspora, were actually used by local politicians at various occasions for questioning the local relevance of Dak'Art.

At this point it seems useful to introduce the concept of "reflexive modernisation," mainly in Giddens' meaning of post-traditional society (Giddens 1994: 56), and in Lash's one of putting together networks, and|or constructing alliances (Lash 2003: 51). As Lash points out, reflexive has to be differentiated from the Cartesian introspective reflective. Giddens' argument emphasises the loss of salience of a particular tradition for reflecting social conditions of life, whereas Lash focuses on the reflexive production which is nowadays connected to "levels of information flow and knowledge acquisition" (Lash 1994: 120f.), or to cultural pluralism of "entangled multiple modernities" (Randeria 1999: 379).

One may wonder whether the category of "second modernity" actually applies to the present Senegalese State - considering that Beck et al. do refer to the Eurocentric perspective of the notion (Beck, Bonss and Lau 2003: 7). The global culture of art biennales, however, corresponds to an advanced system belonging to this second modernity, this is the area of the global art world, which determines contemporary art production. The case of Dak'Art represents a non-European and nonNorth American trajectory in debates and practices of contemporary art. It is included via specific connections within the global culture of biennales, and these connections are conflicting, redefined and ever changing: the contribution of contemporary art of Africa to the global art world, the work of global curators within the selection committees, the travelling artists, specialists, and elite audience. It thus challenges the hegemonic standards of the European-North American art world. 
Political constraints, as well as local, sub-Saharan, and global connections to art expressions are constitutive of the conflicts within this arena.

\section{Conclusion}

At the beginning of this paper, I raised two questions: (1) about the relationship between Anthropology of art and mainstream Anthropology, a question which was related to the relevance of studies in art, and less so to the actual idea of representation; (2) about possible contributions of this sub-discipline to the anthropological study of Modernity.

With my first question I reviewed three major theoretical approaches, which had been formulated during the 1990s, and which are still dominant nowadays in anthropological research. The Anthropology of Aesthetics stems back into the 1970s, and now focuses on the analysis of art objects in connection to aesthetic activities of social agents for structuring their social relationships. Alfred Gell asserts that art is about doing and elaborates two main concepts, which are transformations of anthropological theories: efficacious agency, and distributed mind. The Critical Anthropology of Art of Marcus and Myers focuses on the European-North American art world and its practices of appropriating, or excluding art objects from other origins. Anthropological analyses of these art world practices are important insofar as they unravel broader contexts of these practices, i.e. the production of cultural values, and of images of other cultures, and of incipient (inter)-cultural discourses.

My second theme was dominated by the question where, in times of globalisation, global art becomes visible. For the representation of the biennale of Dakar, Dak'Art, I relied on three concepts. Global culture refers to the global system of art biennales, and to the production, and distribution of diversity within this system. For the specificity characterising Dak'Art, I used Turner's concept of the arena, where conflicting dynamic interactions are occurring, shaping the appearance of each biennial manifestation. I conceive the concept of reflexive modernisation well suited for placing the trajectories of Dak'Art within the global networks, alliances, and cultural flows of the global culture presented in this paper.

Finally: with this paper I intended to introduce to you some areas where the anthropological study of art, and art institutions, may contribute to major questions which are on the spot of researches on global art, without being subjugated under discourses of art history, and I aimed at showing how these anthropological studies are at the same time embedded within social processes of interactions of varying spatial scales.

Thomas Fillitz is Associate Professor of Social Anthropology, and director of the Department of Social and Cultural Anthropology at the University of Vienna. He is the current Secretary of the Executive Committee in the European Association of Social Anthropologists (EASA). His research interests include art worlds and global art, visual culture, globalisation and transnational processes. 


\section{Literature}

Araeen, R. 2003. Dak'Art 1992-2002: The Problems of Representation, Conceptualisation, and Critical Evaluation in Contemporary African Art as Represented by the Dakar Biennale. Third Text 62, 17(1): 93-106.

Banks, M. and H. Morphy. 1997. Introduction: Rethinking Visual Anthropology, in: Banks, M. and H. Morphy (eds.), Rethinking Visual Anthropology. New Haven and London: Yale University Press, 1-35.

Beck, U., W. Bonss, C. Lau. 2003. The Theory of Reflexive Modernization. Problematic, Hypotheses and Research Programme. Theory, Culture \& Society 20(2): 1-33.

Belting, H. 2007. Contemporary Art and the Museum in the Global Age, in: Weibel, P. and A. Buddensieg (eds.), Contemporary Art and The Museum. A Global Perspective. Ostfildern: Hatje Cantz, 16-41.

Benzing, B. 1978. Das Ende der Ethnokunst. Studien zur ethnologischen Kunsttheorie. Studien und Materialien der anthropologischen Forschung 1, 4. Wiesbaden: Heymann.

Biggs, B. 1996. Dak'art '96. Third Text 36: 83-86.

Bourdieu, P. 1992. Les règles de l'art. Genèse et structure du champ littéraire. Paris. Seuil.

Bourdieu, P. 2003. Participant Objectivation. Journal of the Royal Anthropological Institute 9(2): 281-94.

Bydler, C. 2004. The Global Art World Inc.: On the Globalization of Contemporary Art, Acta Universitatis Upsaliensis, Figura Nova Series 32. Uppsala: University of Uppsala.

Clifford, J. and G. Marcus (eds.) 1986. Writing Culture. The Poetics and Politics of Ethnography. Berkeley (et al.): University of California Press.

Coote, J. and A. Shelton. 1992. Introduction, in: Coote, J. and A. Shelton (eds.), Anthropology, Art, and Aesthetics. Oxford: Clarendon, 1-11.

Danto, A.C., 1965, The Artworld. Journal of Philosophy 61: 571-84.

Deliss, C. 1993. The Dakar Biennale '92: Where Internationalism Falls Apart. Third Text 23: 136-141.

El Haji Sy 1995. Art Against Apartheid, in: Deliss C. (ed.), Seven Stories - About Modern Art in Africa. Paris and New York. Exhibition Catalogue, 13-28.

Englund, H. and J. Leach. 2000. Ethnography and the Meta-Narratives of Modernity. Current Anthropology 41(2): 225-48.

Enwezor, O. 2003. The Postcolonial Constellation: Contemporary Art in a State of Permanent Transition, in: Tawadros, G. and S. Campbell (eds.), Fault Lines. Contemporary Art and Shifting Landscapes. London: Institute of International Visual Arts, 65-78.

Featherstone, M. 1991. Global Culture: An Introduction, in: Featherstone, M. (ed.), Global Culture - Nationalism, Globalization and Modernity. London (et al.): Sage, 1-14.

Gell, A. 1998. Art and Agency. An Anthropological Theory. Oxford: Clarendon.

Giddens A. 1994. Living in a Post-Traditional Society, in: Beck, U., A. Giddens, S. Lash, Reflexive Modernization. Politics, Traditions and Aesthetics in the Modern Social Order. Cambridge: Polity, 56-109. 
Hall, S. 2001. Museums of Modern Art and the End of History, in: Hall, S. and S. Maharaj, Modernity and Difference, Annotations 6, ed. by S. Campell and G. Tawadros. London: Institute of International Visual Arts, 6-25.

Hannerz, U. 1991. Cosmopolitans and Locals in World Culture, in: Featherstone, M. (ed.), Global Culture. Nationalism, Globalization and Modernity. London: Sage, 237-52.

Hervik, P. 1994. Shared Reasoning in the Field. Reflexivity beyond the Authors, in: Hastrup, K. and P. Hervik (eds.), Social Experience and Anthropological Knowledge. London and New York: Routledge, 78-100.

Hymes, D. (ed). 1972. Reinventing Anthropology. New York: Pantheon Books.

Jewsiewicki, B. and B. Plankensteiner. 2001. An/Sichten. Malerei aus dem Kongo 1990-2000. Vienna, New York: Springer Verlag and Museum für Völkerkunde Wien.

Kahn, J. 2001. Anthropology and Modernity. Current Anthropology 42(5): 651-80.

Lash, S. 1994. Reflexivity and its Doubles: Structure, Aesthetics, Community, in: Beck, U, A. Giddens, S. Lash (eds.), Reflexive Modernization. Politics, Traditions and Aesthetics in the Modern Social Order. Cambridge: Polity Press, 110-73.

Marcus, G. 1995. Ethnography in/of the World System: The Emergence of Multi-Sited Ethnography. Annual Review of Anthropology 24: 95-117.

Marcus and F. R. Myers. 1995. Introduction: The Traffic in Culture, in: Marcus, G. and F. R. Myers (eds.), The Traffic in Culture. Refiguring Art and Anthropology. Berkeley (et al.): University of California Press, 1-51.

Mauss, M. 1950. Essai sur le don. Paris: PUF.

McEvilley, T. 1993. Arrivederci Venice. The 3rd World Biennals. Artforum Int. 11(1): 1-14.

Randeria, S. 1999. Jenseits von Soziologie und soziokultureller Anthropologie: Zur Ortsbestimmung der nichtwestlichen Welt in einer zukünftigen Sozialtheorie. Soziale Welt 50: 373-82.

Schomburg-Scherf, S. 1986. Grundzüge einer Ethnologie der Ästhetik. Frankfurt/Main: Campus.

Starthern, M. 1988. The Gender of the Gift. Problems with Women and Problems with Society in Melanesia. Studies in Melanesian Anthropology 6. Berkeley (et al.): University of California Press.

Turner, V. 1974. Drama, Fields, and Metaphor. Symbolic Action in Human Society. Ithaca, New York (et al.): Cornell University Press. 